\title{
ONLINE EDUCATION AS AN ELECTRONIC INNOVATION IN BUSINESS
}

\author{
Kaktayeva Nurgul \\ Master student of Economical Studies, \\ Turalin Amirzhan \\ Candidate of Economical studies, \\ Petropavlovsk, Republic of Kazakhstan \\ DOI: 10.31618/ESU.2413-9335.2019.11.60.4-6
}

ABSTRACT.

This article discusses online learning from an economic perspective. The article provides definitions of online education and online schools referring to the Law of the Republic of Kazakhstan "On Education of the Republic of Kazakhstan". It reveals the conditions and technologies needed for online learning programme realization, tendencies of EdTech development and the industry's biggest companies around the world and in the Republic of Kazakhstan.

\section{АННОТАЦИЯ.}

В этой статье обсуждается онлайн-обучение с экономической точки зрения. В статье даны определения онлайн-образования и онлайн-школ со ссылкой на Закон Республики Казахстан «Об образовании Республики Казахстан». В нем раскрываются условия и технологии, необходимые для реализации программы онлайн-обучения, тенденции развития EdTech и крупнейшие компании отрасли в мире и в Республике Казахстан.

Keywords: online training, online school, distance education, electronic technologies, EdTech, information resources, state program.

Ключевые слова: онлайн-обучение, онлайн-школа, дистанционное обучение, электронные технологии, EdTech, информационные ресурсы, государственная программа.

Society is accustomed to the fact that every modern child should receive education in a traditional way; therefore, alternative sources of knowledge seem unusual. It is still questioned whether it is possible to learn something not only from books or school. The Internet has already produced new principles of the material presentation. Plethora of websites offer distant education, and those who are not satisfied with the classical model have switched to the global network

Many parents are afraid that if a child sits at the monitor for a long time, their eyesight will deteriorate. Due to the fact that each student can determine the time and the number of lessons, they will not have to spend so much time in front of PC to harm their health. In addition, there is no longer a need to spend 5-6 hours at an uncomfortable school desk, earning scoliosis.

Sometimes a child should simply have a rest from gaining knowledge. Hence, a change of activity is demanded. Mental work should be alternated with physical exercises, then online learning will be efficient.

Online training is considered as a new level of training, which provides opportunities for the utilization of information technology based on the use of PC, video and audio devices, space and fibre optic equipment. [1]

Online learning is the interaction between a teacher and students at a distance reflecting all the components of educational process (objectives, content, methods, organizational forms, means of learning.) and realized by means of the Internet technologies or other means providing interaction.

According to the law "On Education in the Republic of Kazakhstan", "distance learning technologies" are understood to be training, implemented by means of informational and telecommunication media in case of intermediary interaction between a learner and an educator.

When realizing the online learning program conditions for the electronic informational-educational environment functioning must be created. The conditions include electronic informational information resources, electronic educational resources, information technology technologies, telecommunications technologies, corresponding technologies providing the mastering of students with learning programs of educational programmes in the full volume regardless of the place and location of the students. [1]

Thus, depending on the adopted distance education technology, an educational institution needs to have a range of special facilities that ensure the educational process is carried out according to the chosen course meeting the quality standards of educational services.

There is a large set of tools that can be used to organize the interaction of the student and the teacher. The most widespread in online schools are the following:

1. Email. The advantage is that the student can perform the task at a convenient time, using all the necessary resources. The disadvantage is that the teacher cannot "accompany" and "direct" the student in real time;

2. Utilizing the program "Skype". The program allows you to communicate via the Internet worldwide. In this case, the teacher can give necessary advice directly in the process of doing a work, discuss with the student the steps of its accomplishment, results obtained, make the necessary amendments. Difficulties arise in the visualization of the student's work, as this 
happens either through a webcam, and the signal quality does not always allow this, or via email, which again leads to a "stretch" in time;

3. Google - documents. This resource can be used both while working with documents, presentations, and with tables. At the same time, access to them can be simultaneous, that is, the teacher "sees" how the student performs the task, and they can correct student's work. The drawback of this resource is that there are a number of countries that limit the operation of this browser and the use of its resources becomes impossible;

4. Other tools, such as video conferencing, chat rooms, blogs, forums, etc. [2]

When choosing a technical means of organizing interaction with the student, the teacher should first of all be guided by those that are available to the student due to their age and level of computer literacy, but at the same time it is necessary to introduce him and others gradually, as this creates additional motivation, will make the process more diverse, help improve the quality of learning material.

Despite the "statehood" of the country's educational services market, the conservatism of its participants and their weak IT literacy, investors see enormous potential in Kazakhstan's EdTech.

The volume of the global educational services market is $\$ 4.5-5.0$ trillion, and in the next years it promises to grow steadily, breaking through the mark of $\$ 6$ - 7 trillion. At the same time, the share of online education is about 3\% (\$165 billion). Such data, with reference to foreign forecasts, are provided in Research of the Russian market of online education and educational technologies.

Due to steady growth by 2023, the digital part of the industry promises to overcome the level of $\$ 240$ billion, adding more than 5\% per year. According to a more optimistic forecast, this figure will reach \$ 252 billion even earlier - by 2020 , with an average annual increase of $17 \%$. The United States continues to be the leader in the EdTech market, but the growth rate of this market in the states is slowing down, amounting to 4.0 $4.4 \%$ annually. The second largest region is Southeast Asia, primarily such countries as Kit and India. In these countries, the online education market is gaining momentum much more rapidly, about $17 \%$. [3]

Analysts in KPMG estimate the online education market in India at \$ 1.96 billion. By 2020, the share of Asia in the EdTech-industry is predicted to reach approximately $54 \%$ that is explained by the following factors:

1. In Asia, there are more than 600 million schoolchildren;

2. The population of Asia is "fixated" on obtaining good education and parents are ready to invest exorbitant amount of money in the education of their children. In Singapore, parents spend more than 70 thousand dollars a year for the education of one child, which is two times more than the global average;

3. In China, $53 \%$ of the population now have access to the Internet;

4. Chinese giants such as Alibaba, Baidu, Tencent invest fortunes in the industry. For example, $\mathrm{Yu}-$ anfudao received $\$ 1$ billion from Tencent;
5. Foreign players are also entering the market. For example, Mark Zuckerberg's investment fund invested in Byju's startup (online education in India);

6 . The Chinese government invested $\$ 1.07$ billion in EdTech startups in 2015. The government announced that by 2020 it will have invested $\$ 30$ billion in EdTech;

7. In India, the government launched programs such as Digital India and Skill India to digitize the country. [4]

The capacious Chinese market has spawned six "unicorns", among which there is a stunningly successful online learning platform VIPKID, whose value is estimated at $\$ 1.5$ billion. More than 200 thousand Chinese children and teenagers use this service, which is based on 30 thousand teachers from the USA and Canada. The student retention rate is $95 \%$, and 25 minutes duration tasks brought the company $\$ 760$ million. In 2018 VIPKID ranked 29th in the list of the most innovative companies in the world, becoming the second in China after Tencent. EdTech - reviewers believe that VIPKID achieved such success thanks to three things: strict selection and search for a suitable teacher for each student, one-on-one training, fast feedback and enrollment of students seriously tuned in to learn English.

Russia is the main driver of the EdTech market in the post-Soviet space. The education market in Russia amounted to $\$ 29$ billion in 2016, 1.1\% of which was online education - \$ 334 million. In 2021, online education is predicted to grow to $2.6 \%$ ( $\$ 860$ million).

Considering the small size of the venture capital market in Russia, from 2014 to 2016, only 65 startups received investments worth around \$ 17 million (over three years). $40 \%$ of startups were financed by the Internet Initiatives Development Fund by presidential decree.

Significant players in the Russian market of EdTech are the as follows sions

1. Netology - University of the Internet profes-

2. Foxford - online school to prepare for the USE, PSE examinations and Olympiads;

3. City Business School- a new type of business school that combines elements of classic business education and the latest educational solutions and technologies;

4. iSpring - a platform for corporate training, online testing and creating electronic courses;

5. Geekbrains- educational IT portal;

6. HTML Academy - interactive online programming courses. [4]

As for the Republic of Kazakhstan, the state program for the development of education and science in Kazakhstan for 2016-2019 sets such objectives as increasing the proportion of schools that use ICT in the educational process to $90 \%$ in 2019 . In the Message to Kazakhstani people in 2018, former President Nursultan Nazarbayev noted the importance of developing digital educational resources, posting video lessons from the best teachers so that all kazakhstanis can get access to education, as well as increasing the number of specialists in working with artificial intelligence and "big data". 
The State Program "Digital Kazakhstan" is also aimed at supporting these goals. For example, from 2014 to $2016,14.5$ thousand educational grants for ICT majors were allocated, and the number of graduates over this period amounted to more than 90000 people. The subject "Information and communication technologies" was introduced in 3-4 grades, and 372 circles of robotics were launched.

At the same time, problems with a weak infrastructure, a shortage of staff, an outdated curriculum and a mismatch of the knowledge and skills of graduates to the expectations of the labor market remain unresolved.

Perhaps, the development of EdTech - industry would contribute to solving the abovementioned problems. At the moment, the EdTech market in Kazakhstan is in its infancy and is fragmented. At least, this assupmption follows from the lack of information on the volume of the market and its main players. There are separate university-based initiatives and private startups:

1. OpenAlmaU - Massive Open Online Courses of Almaty Management University;

2. Narxoz Online - the online training center of the Narxoz University

3. Open KazNU - MOOK-platform of Al-Farabi Kazakh National University;

4. OpenU.kz - Open University of Kazakhstan, online courses from leading teachers of the country;

5. Neupusti.net - Portal with information about grants, internships, seminars, trainings and vacancies for young people;

6. Kundelik.kz- Online diary for schoolchildren;

7. Ustudy - Testing centers for preparing students for exams and UNT;
8. Academia.kz- Virtual laboratory of pedagogical skills.

It is difficult to voice any figures by the size of investments in EdTech startups. If you take separate cases to understand the scale, then one of the projects that received international funding can be called Robo Wunderkind, that initially received $\$ 10,000$ as a result of participating in the "Build Your Business" competition in 2013.

In 2015, the team entered Kickstarter and received an investment of \$ 246.6 thousand. From the experience of the MOST business incubator, it can be seen that the hackathons are usually not aimed at EdTech, but at one of the last hackathons, two EdTech projects received \$ 25 thousand dollars of seed investments. [5]

So, the EdTech market in Kazakhstan is at the beginning of its development and there is a huge potential for innovation, since the existing traditional education does not always meet the needs of the modern world. Governmental support and structural introduction of EdTech into all stages of the education system is needed.

\section{References}

1. Kaan, James My first business. How to evaluate the idea of the project and their strength / James Caan. - M .: Mann, Ivanov and Ferber, 2017. - 240 p.

2. Shishin, S. V. Entrepreneurship in the context of globalization. Problems and risks / S.V. Shishin. - M .: Olma-press, 2017. - $352 \mathrm{p}$

3. Ken, Heather Economics of industries and firms. Tutorial / Heather Ken. - M .: Finance and Statistics, 2018. - 480 p.

4. Organization of management. - M .: Economy, 2017. - $231 \mathrm{p}$.

5. Economic analysis of online schools. - M.: SU HSE, 2018. - 328 p.

\section{ПРОБЛЕМА ПРИВЛЕЧЕНИЯ ИНОСТРАННЫХ ИНВЕСТИЦИЙ В ЭКОНОМИКУ РОССИИ.}

\section{Кесаева Д.М. \\ Магистрант \\ Северо-Осетинского государственного университета им. К.Л. Хетагурова \\ г. Владикавказ}

\section{АННОТАЦИЯ.}

В данной статье рассмотрены основные проблемы ввоза и вывоза капитала и формирование прямых инвестиционных потоков в современных экономических условиях, в частности исследована динамика притока/оттока капитала из РФ. Так же представлены основные пути решения данной проблемы.

\section{ANNOTATION.}

This article discusses the main problems associated with capital and the formation of investment flows in modern economic conditions, explore the dynamics of capital inflows from the Russian Federation. It also presents the main ways to solve this problem.

Ключевые слова: инвестиции, иностранные инвестиции, отечественные инвестиции, отток капитала.

Keywords: investment, foreign investment, domestic investment, capital outflow

Инвестиции на сегодняшний день являются важной составляющей современной экономики, они представляют собой размещение финансовых и иных средств, приносящих доход, в предпринимательскую деятельность или другие инвестиционные проекты с целью получения дохода или иного положительного эффекта.
Иностранные инвестиции, безусловно, важны не только для экономики, но и для населения страны. Эксперты считают, что эффективное привлечение инвестиций, а так же их разумное использование позитивно воздействует не только на экономический рост, но и обеспечивает участие страны в международном движении капитала, что в свою очередь гарантирует рост количества рабочих 